\title{
Evangelicals in the Latin American political arena: the cases of Brazil, Argentina and Uruguay
}

\author{
María Victoria Sotelo $^{1} \cdot$ Felipe Arocena $^{1}$
}

Received: 16 January 2021 / Accepted: 9 June 2021 / Published online: 6 July 2021

(c) The Author(s) 2021

\begin{abstract}
The advance of evangelical congregations in the Latin American religious scene is one of the most significant cultural transformations of the last decades. It is so because of the speed with which it has occurred, because of the important number of people involved and because of the depth with which it challenges the Catholic Church, one of the most emblematic institutions of the continent since the conquest. In this paper, we analyze one of the areas in which this religious revolution is manifesting itself in three different countries. We address the changing relationships between evangelicals and politics in Brazil, Argentina and Uruguay and prove that, despite the enormous differences among these three countries, there are clear similarities in the political agendas that evangelicals support. Nevertheless, we also show the different articulations that Evangelicals have carried out in the political arena in each case. The Evangelical churches in Brazil have advanced much more in this sense than in Argentina, with Uruguay being the intermediate situation. For this, we will base ourselves on a bibliographic review of research, in statistical data from the Latinobarometer, together with specific in-depth interviews.
\end{abstract}

Keywords Religion · Politics · Evangelicals · Brazil · Argentina · Uruguay

\section{Introduction}

In line with several authors, we can state that "the public face of religion in Latin America, and in general the presence of religion in the public sphere and in the social and political life of the continent has undergone enormous changes in the last 50 years" (Levine 2006, p. 7).

María Victoria Sotelo

mavictoria.sotelo@cienciassociales.edu.uy

Felipe Arocena

felipe.arocena@cienciassociales.edu.uy

1 Department of Sociology, University of the Republic, Constituyente 1502, Montevideo, Uruguay 
In the not-so-distant past, the public face of religion evoked an alliance between the Catholic Church (only one church was identified) and political, economic and social power. Today the image is different: where there was a monopoly, Levine points out, there is pluralism (a multiplicity of churches, chapels, radio and television programs, pastors preaching on the streets and public squares, religious ceremonies on beaches or in sports stadiums). The weakening of the Catholic monopoly is a long-term process that is just beginning to take hold, and the challenge is to generate a new agenda of studies, approaches and methodologies to understand "the multiple consequences of religious pluralism, both for religion itself, for politics and above all for democratic political life" (Levine 2006, p. 27). ${ }^{1}$

Joanildo Burity (2008) in this same sense also reflects on the link between politics and religion in contemporary times. The author notes that "We can no longer ignore the public visibility of religion in contemporary scene. In terms of culture and daily life, as well as in the public and political spheres, religious actors move and advertise their language, their spirit, their demands, in the most diverse directions" (Burity 2008, p. 84). In the last years, we have witnessed a growing "advance" of movements and situations that involve religious actors (or social and political actors for whom their religious identity is or has become a particularly relevant component) in the central countries. Due to migration (not always recent, but acquiring a new configuration with the emergence of multicultural discourses), remote echoes or direct interventions by religious groups and incidents in countries like the United Kingdom, France, Germany, Australia, religion again is part of everyday life cultural and political, argues the author. In Latin America, the obvious effects of a process of cultural pluralization comes together with the emergence of a field of religions (plural), undermining the Roman Catholic monopoly, but maintaining a Christian monopoly, and the emergence of a new social actor: The Pentecostals (Burity 2008).

Since mid of the 1980s, beginning with the Brazilian case, the emergence of an evangelical bench revealed the complete profile of this new social actor that the social sciences recognized in a belated way, since Pentecostalism had been growing for decades (Burity 2008). It is for this reason that this topic has been chosen, to produce knowledge from sociology about the characteristics of these "new political actors" coming from the evangelical world-mainly neo-Pentecostalism-in the Latin American political arena.

The purpose of this article is to analyze the recent expansion of evangelicals and how it impacts the political arena of three countries: Brazil, Argentina and Uruguay. We believe that the comparison of these three countries in the southern cone is a relevant new contribution to the already vast area of research on Evangelicals in Latin America as a whole, or in single countries, as we do not know of previous works focused on this triad.

\footnotetext{
${ }^{1}$ See also Mallimaci (2008), Joanildo Burity (2008), Mallimaci and Cruz Esquivel (2013).
} 


\section{Classification of evangelicals}

What we call "evangelism" refers to different religious groups' inheritors of the sixteenth century schism: Lutherans, Methodists, Calvinists, Baptists, Mennonites, Presbyterians and Pentecostals, among others.

Protestantism, antecedent to all the evangelical churches, is a Christian movement that bases religious authority on the Bible and opposes the infallibility of the Pope (Semán 2019).

Being an evangelical does not imply being registered in a bureaucracy, it consists of a personal encounter with Jesus, the Holy Spirit and God the Father. "Every believer is at the same time a priest" (Semán 2019, p. 27).

There are three evangelical tendencies in Latin America:

(1) Historic Protestantisms (they arrived in the region in the nineteenth century and were limited to migrant communities): Lutherans, Methodists, Calvinists.

(2) Evangelical tendencies (originated in the USA, arrived in Latin America since the beginning of the twentieth century, with a missionary and proselytizing sense): Baptist, Presbyterian and Free Brothers Churches.

(3) The Pentecostals, sustain the actuality of the gifts of the Holy Spirit (born in the early twentieth century, Azusa Street, California African Methodist Episcopal Church, 1906, events similar to those of Pentecost). Neo-Pentecostalism (late 1960s and early 1970s) exacerbates features of Pentecostalism (miracles, role of shepherds) and two key theological articulations: the "theology of prosperity" (Semán 2001) and "spiritual warfare” (Semán 2019, pp. 31-32).

\section{Materials and methods}

The objective of this article is to carry out a comprehensive review of the presence of evangelicals in the political arena in Brazil, Argentina and Uruguay. For this, we will do a bibliographic review of research published in the three countries, as well we will process secondary data from the Latinobarometer ${ }^{2}$ (2018) to characterize the presence of evangelical believers in Latin America, the continent where the countries chosen for this study come from. We also use in-depth interviews with different actors in the three countries, carried out specifically for this research.

Despite the fact that the presence of evangelicals in politics is evident throughout the continent, we chose for this article to analyze what is happening in the southern cone countries (Brazil, Argentina and Uruguay). The choice of cases is due to the fact that they are three neighboring countries, but present very different religious and political realities.

\footnotetext{
${ }^{2}$ Latinobarómetro Database (latinobarometro.org).
} 


\section{Percentage of evangelicals in Latin America}

(2018)

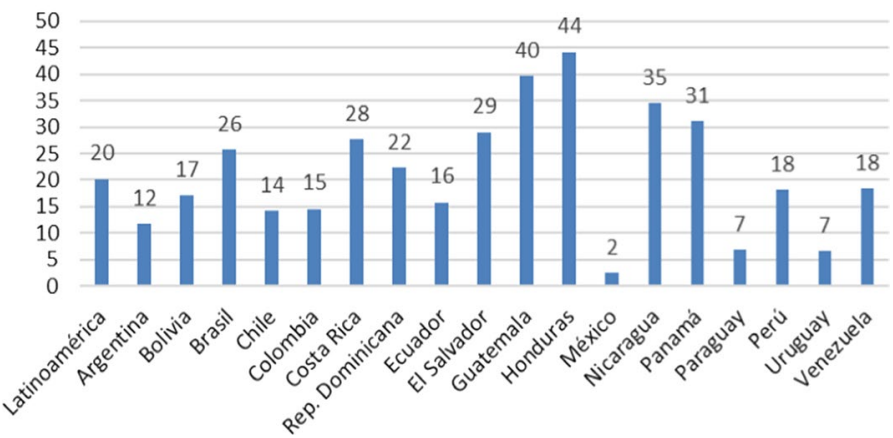

Figure 1 Percentage of evangelicals in Latin America (2018) Source Own elaboration based on Latinobarómetro (2018)

\section{The numerical presence of evangelicals in Latin America}

In Latin America, the region where the current Pope "Francisco" (the Argentinian Jorge Mario Bergoglio) comes from, 59\% of the population is defined as Catholic, according to data published by the Latinbarometer in 2018. In 1996, the percentage of Catholics reached $80 \%$ of the Latin American population, indicating a decrease of 21 percentage points in the space of two decades. A true cultural revolution in a very short period of time. This cultural revolution is called evangelism. Today, one in five Latin Americans profess evangelical Christianity: 20\%. According to the Latinbarometer (2018), the evangelical population in each country represents as follows: Argentina (12\%), Bolivia (17\%), Brasil (26\%), Chile (14\%), Colombia (15\%), Costa Rica (28\%), República Dominicana (22\%), Ecuador (16\%), El Salvador (29\%), Guatemala (40\%), Honduras (44\%), México (2\%), Nicaragua (35\%), Panamá (31\%), Paraguay (7\%), Perú (18\%), Venezuela (18\%), Uruguay (7\%) (Fig. 1)

In several Latin American countries (Argentina, Mexico, Peru, Chile, Costa Rica, Colombia), Evangelicals have demonstrated in marches against abortion, against gay marriage and in defense of the traditional family, in alliance with Catholics. In any case, we see that this religious conservatism clashes with an immense number of Latin Americans who define themselves as "non-believers", $16 \%$ according to the Latinobarometer (2018), a figure that is growing year by year. This means that we are facing a very polarized scenario in the region, where there are also demonstrations by citizens who claim the secularity of the State, by not sharing the religious positions of these groups on issues of family, gender or reproduction (Fig 2).

One of the most outstanding academics who has studied the evangelical phenomenon in the world, Freston (2012), emphasizes that the religious changes in Latin America are due to conversion. They are changes "from within" (not due to the actions of foreign missionaries, nor by immigrants) and "from below" (not due to national reform). That is why the transformations in the relationship between religion and state (and politics) are very complex. "As a result, the region clearly differs 


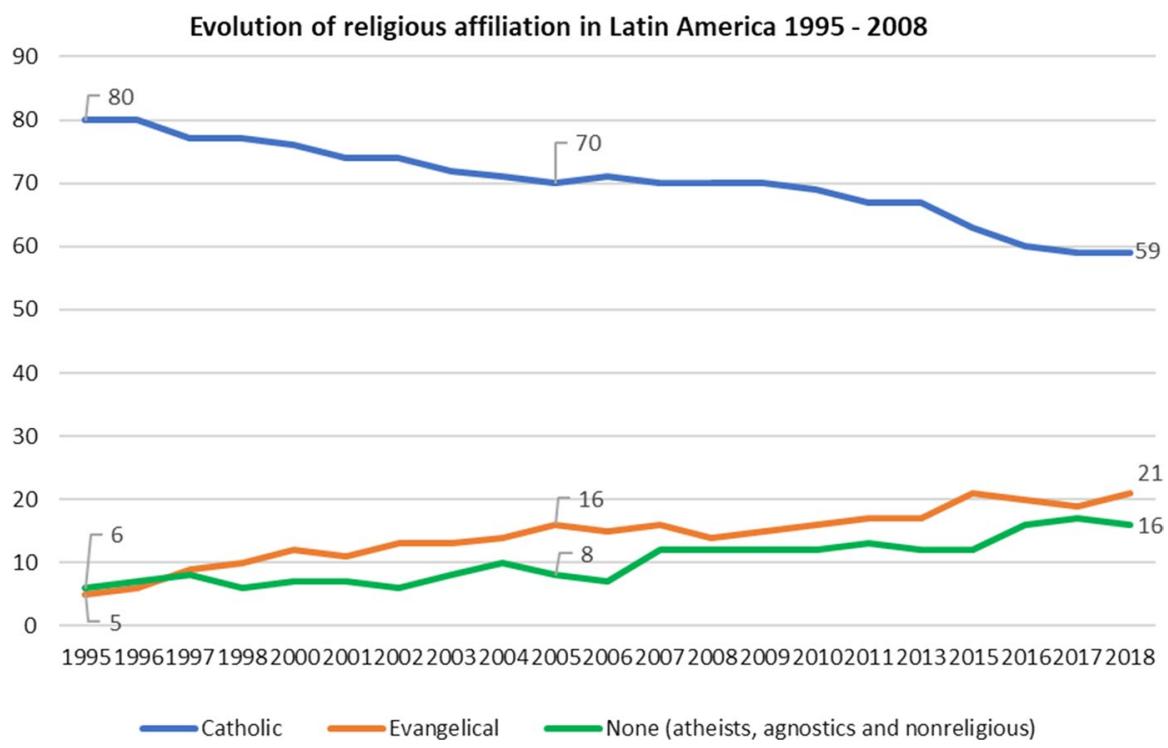

Figure 2 Evolution of religious affiliation in Latin America (1995-2018) Source Own elaboration based on Latinobarómetro (2018)

from Europe, where the new religious pluralism results from immigration and secularization, with implications for debates on the incorporation of religious diversity into the public sphere. There is a fundamental difference (in terms of cultural and political implications) between diasporic globalization and conversionist globalization. In this sense, Pentecostalism is vital as a driver of religious and religious-political change. It is Pentecostalism that structures the emerging model of the religious field, a model that includes many other actors but of which Pentecostals have been the main creators, in many ways. First, because of its numerical success in the whole region, Pentecostalism is already the second religious force, with the exception of Uruguay where it has been overtaken by the 'religionless'. Secondly, because of its effect in 'Pentecostalizing' other sectors of the religious field (either by imitation as in the Catholic Charismatic Renewal, or by the hostile reactions that lead to modifications in the rival religions)" (Freston 2012, p. 82).

Nevertheless, for the author, the Protestant transition in Latin America will have a ceiling, since there is a hard core of Catholics that will not be eroded, owing to the fact that Catholicism is modifying its strategies and has learned to compete better. On the other hand, the evangelical image is sometimes charged with negative visions, scandals, authoritarian images, unfulfilled promises, etc. That is why eight years ago Freston (2012) predicted that the Protestant transition in Latin America would reach - in some countries before others-a standstill and a subsequent fall.

Contrary to this hypothesis, our work shows that this ceiling was clearly not reached and, on the contrary, it is increasingly being seen in virtually all Latin American countries. As we anticipated at the outset, Latin America's religious transformation must be seen as one of the most dizzying cultural changes in the entire 
region. The speed and scope of this social change is reflected in new relationships between religion and politics. As in the three cases analyzed, in other Latin American countries evangelicals are mobilizing against bills, in some they have their own political parties and even presidential candidates. The president of Guatemala, Jimmy Morales, is an evangelical (a staunch opponent of abortion and gay marriage). In Mexico, an evangelical-based party supported President Andrés Manuel López Obrador, who repeatedly quoted the Bible and the Gospel in his speeches. Even in a country like Costa Rica, the support of the evangelical candidate Fabricio Alvarado was surprising. In Venezuela and Colombia in 2018, two evangelical pastors (Javier Bertucci and Jorge Antonio Trujillo, respectively) ran as presidential candidates. For these reasons, we can affirm that the evangelicals are advancing strongly on the map of power in Latin America. This change can be glimpsed in the new strategy that was outlined in many countries and in particular in Brazil, when already from the 1980s the motto "a believer does not get involved in politics" was modified to "brother votes brother".

\section{Understanding religion and its link with politics in Latin America}

To analyze the actions of evangelicals in the Latin American political field, Segato (2008), argues that the trends of contemporary religiosity respond to a new territorial order in late modernity. Segato (2008) states that in times of globalization and identity politics, "the expansive process of some religions can be described as soft annexation, where the signs of religious affiliation mark the belonging to a network and anticipate the acquisition of new territories. In this new territorial order, the people themselves, with their association capacity, are constituting and annexing territories" (Segato 2008, p. 58). In this context the nation state is weakened and the territories are defined by the adhesion of their inhabitants to a culture, this defines a new territorial order. The people identify themselves with certain emblems and icons and thus define a territory that transcends the nation state. "Groups that behave as secondary patriots in their forms of organization appeal to loyalty and the ritualized display of formulas that express that loyalty, and expand by creating bands of common identity and territorial appropriation" (Segato 2008, p. 44).

These herd peoples maintain a link with nation states in two ways: on the one hand, they cross, with their new form of sovereignty and group loyalties, the old patriotic territories, and interact with more than one nation state, negotiating their status of existence within their jurisdiction and pressing to be recognized as such. On the other hand, their ability to conquer portions of influence and control in one or more fields of economic and political life is a consequence of their existence and cohesion.

This model of analysis proposed by Segato fits very well to understand the advance of Evangelicals in the political arena in different countries of Latin America, transcending the borders of nation states. In this sense, we could say that the evangelical faithful (flock) vote for the evangelical representatives in politics, in this sort of "tribalization of the State", of the factionalism of the Republic in which due 
to soft annexation, there is a generation of affiliations that generate cohesion from an exacerbation of emblems to the detriment of theological discussions.

In order to understand religion today and its link with politics, economics, society, culture and symbolism in Latin America, we must look at a twofold process. On the one hand, the diversified presence of religious people, groups and organizations in various spheres of the public and private spheres. And on the other hand, the mutual transfers, legalities and dislocations in what we can call the space of power and symbolic efficacy where politics and religion are combined. "We are experiencing both a politicization of the religious affairs and a religious indoctrination of politics" (Mallimaci and Cruz Esquivel 2013, p. 4).

Recently the sociologist Bayce (2017) reflected on the growth of Evangelical Pentecostals and Neo-Pentecostals throughout Latin America since the 1980s in both religious and political terms. For the author, this growth is linked to "a conservative, reactionary, quasi-fundamentalist spiritual resurrection of the "New Right" or "Moral Majority" in the USA, which emerged in 1974, and from there, and initially with Ronald Reagan, it supports the American political-ideological right throughout the world" (Bayce 2017). Since 1913, President Roosevelt pointed out that it would be difficult for Latin American countries to be absorbed as long as they were Catholic. The Rockefeller Report (1960) explicitly stressed that Latin America had ceased to be reliable in religious terms because the Basic Ecclesial Communities in Brazil and Liberation Theology throughout South America-especially the Andean region and Brazil-radically led the masses and social groups, among other less aggressive tendencies in other countries, such as Chile and Uruguay. "Liberation Theology had to be fought by supporting conservative beliefs that moved away from justicier intervention in the world, such as the Umbandist religions and the neo-Pentecostal churches. These ideas are reflected in the document of the Santa Fe Committee (1980), and a new document from 1984 recommends "the continuation of the conservative revolution [...] the strengthening of ties with the conservative sectors of the Catholic Church [...] and that Liberation Theology be fought by all means" (Bayce 2017).

Nevertheless, he argues, it would be a simplification to think that the growth of these churches can be explained only by the trilogy of religious conservatism (Protestant, Catholic and Jewish) that has been in command in the USA for almost forty years. "There are powerful economic and social reasons that fertilize the ground for these childish theologies, neo-magical hopes of daily bonanza, to be sown and harvested abundantly in Latin American soils and even to surprise many, among them those who trusted excessively in the legendary Uruguayan rational secularism". The author states that the first generation born after the war has unsatisfied needs, both because of the current economic and social order, as well as the available belief system. The middle and lower classes have a consumerist and hedonist desire promised and not fulfilled by the installed welfare state. The rational and progressive pursuit of these goals and the failure to obtain them discredits the State and awakens the search and hope in symbolic and saving goods.

According to the author, Pentecostal or evangelical beliefs are part of the supply in a market of symbolic goods which is chosen by the middle classes who are threatened with downward mobility and those who do not have access to the package of 
goods and services which the State is reducing. "But these symbolic goods are not totally dissociated from the need for material goods, whose provision is magically entrusted to demonic healings and acts of faith, generally supported monetarily, of course, in the absence of the State's sufficiency in providing for the growing and scientifically fueled desire" (Bayce 2017).

Finally, in this introduction to the topic, it is worth highlighting a particular feature of our continent, as pointed out by the Argentine anthropologist Cernadas (2014), where the evangelical preaching is mixed with the indigenous beliefs generating a mixture. This author, in tune with others (Vilaça and Wright 2009) points out that "the spread of Pentecostal Christianity among Latin American indigenous peoples is revealed as a cultural phenomenon that historically crosses the second half of the twentieth century. The countries of the region thus witness multiple cases of appropriation of the evangelical message by indigenous groups immersed in specific local and national circumstances" (Ceriani 2014, p. 14). This aspect must be taken into account in the analysis since it shapes social and cultural phenomena that we cannot ignore, being one of the factors in which the growth of evangelicals in the region is rooted.

In any case, it is worth noting that, "the important thing about these cultural crossings is not their hypothetical 'hybrid' character -was there ever anything 'pure' before?", wonders Wright (2008). From the point of view of an anthropology of symbols, he points out that there are no pure belief systems, since if there were, it would have to be maintained that there is a zero moment in the origin of the species, which for the author, "is only an ideal of the evolutionary sciences of the eighteenth and nineteenth centuries. Thus, by definition, all socio-cultural systems are fusions of previous forms, in a constant, unfinished and endless spiral" (Wright 2008, p. 96).

In the three sections that follow, the crosses between evangelicals and politics in Brazil, Argentina and Uruguay will be analyzed.

\section{Evangelical power in Brazilian politics}

Since the colonial period, Catholicism has been the main religion in Brazil. Jesuits, Carmelites, Benedictines, Franciscans, among others, settled in the country from the sixteenth and seventeenth centuries. Catholic worship was the official religion of the Empire until the Constitution of 1891, the first written after the proclamation of the Republic. However, the Catholic Church, despite having lost its official status, continued to significantly influence Brazilian politics and society during the twentieth century (Lacerda and Brasiliense 2019).

Beginning in the 1980s, these churches began to adopt a model of corporate representation and consequently engaged in electoral contests with "official candidates" and ran for offices in the municipal, state, and federal legislative branches. The best-known case is that of the Universal Church (IURD), which during the 1990s, elected dozens of bishops and pastors to the Chamber of Deputies, State Assemblies and Municipal Chambers (Lacerda and Brasiliense 2019). The growth of the evangelical population, linked to the opening of the Brazilian "religious market" and the specificities of the electoral system (proportional 
representation of the open list with high-magnitude districts), was one of the main causes that pointed to the increase in the number of Evangelical representatives in Brazilian politics.

It is important to discern between evangelical faith candidates and those supported by Pentecostal churches. It is the latter who, thanks to the institutional resources coming from the churches, have increased their expression in the Brazilian legislative powers.

The number of evangelicals elected has grown between 2002 and 2014, but most of them are corporate representatives of Pentecostal churches. In any case, the presence of evangelicals in the Chamber of Deputies is still far from reflecting the proportion of evangelicals in the Brazilian population. The churches that launch "official candidates" are few but have a high success rate, well above those of the political parties. The IURD, perhaps the most famous Pentecostal church in Brazil, was founded in 1977 in Rio de Janeiro by Edir Macedo. Since then, it has presented an extraordinary growth and has expanded throughout the Brazilian territory. This church has considerable media influence, it controls a national network of AM and FM radios-Red Aleluia-, in addition to the Record de TV station. Besides being the most famous church, it is also the Brazilian Pentecostal church most associated with political and electoral success. According to Lacerda and Brasiliense (2019, p. 258), "the IURD elected $70 \%$ of its candidates in the 2014 elections".

The phenomenon of evangelical political-electoral mobilization is limited to the success of a few large Pentecostal churches that opted for corporate representation (Assembly of God and Universal Church).

Taking the typology of Pérez Guadalupe (2019), we can say that in 2018 an "evangelical front" was formed in support of Bolsonaro, who despite not fully identify himself as an evangelical-his wife did-came to represent the conservative thinking of most of the evangelicals - and catholics - on issues of value. Thus, in Brazil we find the presence of the three models characterized by Pérez Guadalupe and Grundberger (2019): (1) evangelical parties; (2) the evangelical front; and (3) evangelical factions, that is, the nomination of evangelicals in different political parties that later reach seats, and join temporarily in an "evangelical bench ". What is particularly novel in this country as we mention, is the "corporate representation model", which focuses on the nomination of official candidates by Pentecostal Churches (Freston 1993; Lacerda and Brasiliense 2019).

In Brazil there are evangelical parties, such as the Brazilian Republican Party (PRB), which belongs to the Universal Church (IURD), and in which all the candidates of this church nominate. There is also the Social Christian Party (PSC), which represents an important sector of the Assemblies of God, although not all assembly members are running for that party (Pérez Guadalupe 2019, p. 84). It should be noted that the parties with the greatest evangelical representation (PRB and PSC), even when electing benches in the legislatures, have little expression in the elections for the executive. The Assemblies of God constitute the largest denominational confederation in Brazil and with the most quantity of deputies.

After the failure in 2014 of the candidate for the presidency for the PSC Everaldo Días Pereira, who only obtained $0.75 \%$ of the votes, evangelicals are more aware of their possibilities. Therefore, in 2018 they focused on achieving positions in the 
Legislative Chambers and supporting Bolsonaro. Marina Silva, the evangelical candidate, only obtained $1 \%$ of the votes.

At the moment, Evangelicals have a bench with dozens of parliamentarians in the Brazilian Congress and a pastor who is the mayor of Rio de Janeiro. The current president Jair Bolsonaro, as we mentioned, reached the presidency with the support of the evangelicals. In spite of defining himself as a Catholic, Bolsonaro was baptized by an evangelical pastor in the Jordan River, in Israel, in 2016, in what many consider his first act of campaigning. Oualalou (2019) points out that Bolsonaro maintains this "productive religious ambiguity". He became an evangelical while remaining a Catholic, and he is the first President to have an openly Pentecostal speech. This was evident in his first speech after his victory, when he explicitly placed his mandate under God's supervision, recalling his campaign slogan: "Brazil above everything, God above everyone" (Oualalou 2019, p. 69).

According to Oualalou (2019), "Brazil is experiencing an accelerated religious transition, unique in the world for a nation of its size" (p. 70). The author notes that in 1970, 92\% of Brazilians declared themselves Catholic, while in 2010 the percentage dropped to $64.6 \%$. While this decline may be due to greater religious diversity, it has mainly benefited the so-called evangelical group, which includes traditional Protestants, whose weight has not varied much among the population and, above all, the followers of the Pentecostal and neo-Pentecostal churches. In 2010, Evangelicals reached 22.2\% of the population (IBGE Census 2010, quoted by Oualalou 2019).

Oualalou points out that there is a clear correlation between adherence to evangelism and the vote for Bolsonaro, since in the states where evangelism has gained a presence (such as Rio de Janeiro) they have offered the former army captain an overwhelming victory (p. 70). Several factors have been identified by Oualalou to explain Bolsonaro's victory, which he considers to be a "hurricane, a tsunami or a perfect storm", the result of the alliance between the military, the neoliberals and the evangelicals. First of all, Bolsonaro manages to capture the discontent of the sector of the population opposed to the "era of rights" in favor of minorities (women, aborigines, homosexuals). Also, a sector of the population understands that the PT has been a corrupt government that has taken care of the LGTB minorities and the poorest through the interventionism of the state, but has forgotten about them. All this, added to the support given by the Universal Church of the Kingdom of God, the diffusion of fake news, supported by the social networks of Whatsapp and the Record network (the second most watched channel in Brazil, a media tool of the Universal Church) achieve a great capillarity among evangelicals. Under the slogan "Brother votes Brother", all the evangelical churches, from the traditional to the neoPentecostal, called to vote for Bolsonaro in the 2018 elections.

For several years now, Brazilian researchers have been addressing the presence of Evangelicals in the political arena in Brazil. We will analyze some of the most relevant research. Oro (2003) reaches some conclusions that are important to highlight. First, Evangelicals follow and accept the rules of democratic life and the established political game. Second, because of their critical discourse against certain unethical political procedures, because of their denunciation of the difficult situation in which large sectors of society find themselves, they contribute, even if indirectly, to the consolidation of democracy in Brazil. Third, 
Evangelicals constitute a source of political mobilization of disadvantaged social sectors. For many people, says Oro, participating in a church like the IURD is their first experience of talking about politics and valuing the vote. If that happens for certain social segments, politics does not pass through the traditional instances of its expression, such as unions, cooperatives and political parties. The author concludes his article by pointing out that being evangelical has become a new variable in this game of relations between the political and religious fields, which is why "a good epistemological position would be not to underestimate the evangelical insertion in politics (Brazilian and Latin American), reducing it to a simple manifestation of a corporate religious culture, but to overvalue it, seeing it as a potential for the democratization of the Brazilian political culture" (Oro 2003, p. 65).

Oro and Tadvald (2019) also point out that the insertion and the evangelical presence in the political field adopted different characteristics from those of Catholicism, since the Catholic Church rejects the participation of members of the clergy in political positions that are accessed through suffrage. This does not mean that the Catholic Church distances itself from political life, but it generally acts through lobbying and pressure on the authorities and political powers, thus regulating and legislating on public policies that are in line with Catholic principles. However, Evangelicals elect their own representatives in the Legislative Power to defend the principles and values of their church, a phenomenon that has occurred since the $1980 \mathrm{~s}$, when they abandoned their aversion to politics. The main reason for mobilizing the electorate composed of followers and advocates of these churches is, according to Oro and Tadvald, to disseminate Christian morality in the political space and to transform Brazil into a nation guided by God. "Parallel to this moralizing discourse, there are also several non-explicit reasons that lead churches to enter politics: to obtain favors and concessions - such as radio and television frequencies - and to receive concrete support for welfare projects" (Oro and Tadvald 2019, p. 64). The authors conclude that the evangelical Pentecostal countryside is an option designed for the poorest social sectors, urban individuals without qualified training, and those who leave the rural environment in search of a better quality of life in the cities. Pentecostal and neo-Pentecostal churches welcome all of them, with a discourse that is "coherent and valuable to these consumers, and the same can be said of the ritual creativity that characterizes these churches, inasmuch as it is to the liking of those consumers who choose them" (Oro and Tadvald 2019, p. 67).

Mariano (2005) points out that although the social composition of Evangelicals is no longer restricted to the poorest strata, Pentecostals continue to grow mostly at the base of the social pyramid. Pentecostal and neo-Pentecostal churches do not grow because they are passive repositories of anomalous individuals, contrary to what ancient sociological theories might explain. "They grow rapidly because they work hard and know how to exploit, for their institutional benefit, the socio-economic, political, cultural and religious contexts in which they are inserted", says Mariano (2005). For the author, the success of proselytizing with the poor masses is the result of his determined effort and commitment to attract, persuade and recruit them by means of a systematic offer of magical-religious services with strong popular attachment, and the holding of highly emotional cults. All this added to the personal and 
electronic propaganda spread in night hours, of well-narrated testimonies of conversion, blessings received and miracles granted.

The Pentecostals excluded themselves from public life until the 1980s. During the most repressive period of the Brazilian dictatorship, the military governments, deprived of Catholic support and therefore interested in achieving new social bases to legitimize their authority, managed to establish alliances with various evangelical leaders (Protestants and Pentecostals), since many of them were endowed with a genuine and fierce anti-communism, inclined, in many cases, to clientelism and, in conditions of representatives of a religious minority that was discriminated against, eager for resources, social and political recognition. In any case, Mariano (2005) emphasizes that these religious remained for the most part distant from the political-partisan game during the dictatorship, alienated from the political activism of Catholic groups considered progressive, such as the Basic Ecclesial Communities. Towards the mid-1980s, there was a reversal of beliefs, where several Pentecostal churches changed their political behavior; the motto "a believer does not get involved in politics" was thus replaced by the motto "brother votes for brother". The substantial change in the political behavior of Pentecostals occurred at the time of the country's redemocratization (1987-1988), when the "Evangelical Party" was elected, composed of 32 federal deputies (18 of them Pentecostals). Thus, the Pentecostal representation which barely had two members of parliament, increased $900 \%$.

Maria das Dores Campos Machado (2018) is recognized in the Brazilian academia for her contributions to the study of the dissemination of Christian discourse on "gender ideology" in the political and civil society spheres by Catholic and evangelical actors, who reject the adoption of the category of gender in public policies. The author shows the articulations of Catholics and Evangelicals in the National Congress to reverse some policies that incorporated the gender perspective, and in turn, the actions of Catholic and Evangelical leaders in civil society in an attempt to avoid the inclusion of the gender perspective and sexual orientation in state and municipal education plans (Campos Machado 2018). "We are facing a dispute that involves organized segments in social movements, NGOs and confessional institutions with very different world views and interests: Christians with a historical reading of the Bible, with a heteronormative and patriarchal conception of society, and social sectors that value the autonomy of subjects over their bodies and sexuality" 3 (Campos Machado 2018, p. 13). This is a moral dispute and the social construction of a new form of morality by social movements.

Silveira Campos (2005) analyzes how the political behavior of Brazilian evangelicals and Pentecostals changed during the last half of the twentieth century, moving from a rejection of politics to an active and committed participation. Thus, he elaborates two ideal types: the "Evangelical Politicians" and the "Politicians of Christ", who assume a militancy as a "missionary vocation", as a "divine call". "The former build their careers with a discreet support of the churches, while the latter are" produced "by Pentecostal mega-churches, which select, promote and make their election possible. In return, they owe fidelity to the churches and their hierarchies,

\footnotetext{
${ }^{3}$ Own translation.
} 
having, in the legislative chambers, defend the corporate and moral interests of the institution "(Silveira Campos 2005, p. 157).

The insertion of evangelicals in politics is due to the fact that evangelical churches, especially Pentecostal and neo-Pentecostal churches, "find a favorable context for acting as mediators of the relationship between society and State" (Lopes Cabral 2006, p. 92). In the current context, the mediation formerly carried out by political parties between society and the State is losing relevance, and democracy is spreading to broader spaces of civil society. Lopes Cabral (2006) points out that, in Brazil, evangelical churches reach marginal areas of society and manage to mobilize communities in a way that conditions their option when voting. According to the author, they are spaces where the State does not reach, constituting these churches as a relevant actor when it comes to mediating between the new demands of society and the State.

\section{Evangelical politicization in contemporary Argentina}

Before the return to democracy in Argentina (1853), the evangelical world was dominated by a missionary paradigm, the emphasis on the preservation of a denominational identity, apoliticism and social isolation (Carbonelli and Jones 2015). In the 1960s, a fracture occurred, part of the evangelical community (Methodists, Waldenses, Lutherans) approached the Liberation Theology, and others (churches like the Free Brothers and the Salvation Army) are incorporated into the fundamentalist current of the American post-war context and strengthened by the New Christian Right wing. The coups d'état of the 1970s in the Southern Cone accentuated this division, with the first block of churches supporting the progressive Catholic sector and the Ecumenical Movement for Human Rights, and the other supporting the civic-military dictatorship in Argentina. "The return and consolidation of the democratic regime in Argentina favored a growing participation of Evangelicals in the public space during the 1980s and 1990s. Proselytizing campaigns by Pentecostal leaders led to the constitution of an evangelical social movement for the emergence of a common identity. In turn, Pentecostal leaders modified their relationship with worldly structures, accepting to participate in them to transform society from an evangelizing perspective" (Carbonelli and Jones 2015, p. 145).

In the same vein, Hilario Wynarczyc (2009) emphasizes that since the return to democracy in Argentina, Evangelicals have developed a strong identity as the main religious minority based on protest for religious equality in the face of the privileged status of the Catholic Church in that country. A cycle of mobilizations was carried out from 1990 to 2001. This movement "of few people" as Wynarczyc calls it (2009) did not cease to feel stigmatized but had its impact on journalism and the judicial and legislative branches. The evangelicals knew that in 1994 there would be a constitutional reform, and they counted on a certain openness in the Secretariat of Worship of the Nation led by liberal Catholics (in contrast to the nationalist right wing that associated the Church with "being national"). "Under these circumstances they developed a growing protest movement that reached its peak in massive concentrations in 1999 and 2001. The evangelicals did not obtain 
any legal results, as a result of a zero-sum game between the parties involved, but they became a public subject in the civic life of the nation" (Wynarczyc and Oro 2012, p. 30). In 2001 Argentina was going through a political and economic crisis, and the evangelical mobilization decreased. They held only one rally in 2003, with less success, and then abandoned collective action. In this process of mobilization, believers from the entire evangelical spectrum were involved but the center was among the biblical conservatives, and the Pentecostals played an important role as well.

With the democratic restoration, as we have already mentioned, the evangelical churches acquire greater demographic weight and public visibility, establishing new relationships with civil society and the State. They mobilized for a new Law of Worship that would establish real equality between religions, especially for the evangelical churches in contrast to the Catholic Church, since in article 2 of the National Constitution it appears "The federal government supports the apostolic Roman Catholic cult ".

Starting in the 1990s, evangelicals were constituted as a new collective actor in the civic sphere, using various techniques of civil action to gain equality: legislative lobbying, dialogues with Catholic bishops, concentrations in front of Congress, and on a massive scale, in the Obelisk (city center), inclusion of issues in favor of neglected sectors. The most important collective mobilizations were two massive events in the Obelisk of Buenos Aires, on September 15, 1999 and 2001. On November 1, 2003 they organized a "Third Obelisk" but their participation was very modest. After that, the evangelicals gradually ceased the collective protest action.

Evangelicals have tried to "resacralize society" from a biblical perspective and against the postmodern secularization phase (Wynarczyc 2019) based on the participation of party politics, both through the creation of evangelical parties, as well as the collective and individual participation in existing parties. In this sense, they have had little or no success in naively thinking that the "Brother votes for Brother" principle could be fulfilled, something that happens in Brazil and almost exclusively in that country.

The little theological training and the political naivety of the Pentecostals at the head of the confessional parties led them to failure in several electoral campaigns $(1993,1994,1995)$, that is why they abandoned the idea of an electoral participation with their own confessional party, and they joined existing political parties, from the Christian Democracy to the Social Pole, within what Pérez Guadalupe (2019, p. 94) categorize as "Evangelical faction".

What is particular about the Argentine case is that the majority of Argentine evangelicals are not linked in their electoral preferences to parties of the right, but of the center-left. One of the great actors of the Argentine political-party system is Peronism, which functions as a party that appeals to the population from whose origin the Pentecostals arise. The adherence of the population to Pentecostalism occurs in a higher proportion in the territories where people of low and middle-lower class live. That is why there is the particularity that Pentecostals, as they mostly come from the lower levels of the social pyramid, are at the same time voters of Peronism (Wynarczyc 2019). In sum, in evangelical settings, church affiliation and vote orientation function in different ways. 
At present the evangelical churches have defined their new route around the prolife and pro-family moral agenda, which gives them a new visibility and relevance in terms of their relations with certain sectors of the Catholic Church, since they share the struggle for the same agenda (Perez Guadalupe and Grundberger 2019). ${ }^{4}$ The central point of this vision is the fight against the so-called "gender ideology", an ideology that seeks to dominate humanity through international organizations such as the United Nations, non-governmental organizations.

In contrast to what happens in other Latin American countries, where evangelicals are the protagonists of pro-life and pro-family initiatives, in Argentina they act as "escorts" of the Catholic Church, which is the one that occupies the leading and outstanding place. In this sense, they are companions of the Catholic Church and are not the main protagonists in these mobilizations.

In the "secular cycle" of the 2000s (Wynarczyc 2019) we find the participation of Evangelics in existing parties. In the city of Buenos Aires and Greater Buenos Aires, during four elections between 2003 and 2009, there were fourteen evangelical candidates for mostly legislative positions, scattered from the anti-Kirchnerist Peronism to the liberalism of the PRO. Those fourteen people only got three charges. It was then that Cynthia Hotton, from the Free Brothers Church, became a national deputy. In 2011, she lost that bench.

As of 2010, in the city of Buenos Aires, in the municipalities of the Buenos Aires suburbs and in several provinces, the phenomenon of evangelical nominations in existing political parties was evidenced. Approximately 107 people applied, and only $10 \%$ succeeded (Wynarczyc 2019, p. 214). The evangelical applicants came in $48 \%$ from parties related to non-official Peronism (anti-Kirchner) and 3\% to minor variants within Peronism, which adds up to $51 \%$. On the other hand, $34 \%$ militated in the ruling Peronism of the Front for Victory (Kirchnerism). The sum allows us to infer that $85 \%$ were framed in Peronism, another $10 \%$ were in Values for my Country, by Cynthia Hotton, this being the only denominational group. All this leaves us the lesson that the adherence of the evangelical postulants to variants of liberalism (impregnated with evangelical-conservative empathy) and to social democracy was a minority; the majority adherence was clearly to Peronism (Wynarczyc 2019, p. 215).

Cynthia Hotton, an evangelical, was elected to parliament in 2007 as a member of an alliance of non-Peronist parties. In 2008 she formed the political grouping "Values for my country". She follows the conservative line of the mega-Pentecostal church: rejection of the legalization of abortion, rejection of same-sex marriage. She defines the family as a patriarchal and heterosexual institution. One of her proposals was to extend the prerogatives of the Catholic Church to other religions, which did not prosper (Carbonelli 2016). "Hotton obtained a distinction from the international organization Focus on the Family, as 'defender of life in Latin America', and this mention earned her the organization of her own cycle of conferences, where

\footnotetext{
4 The evangelical churches protagonists of this ideological-evaluative turn were substantially those of the biblical conservative pole (the Pentecostals, Free Brothers, Baptists and Mennonites). The Pentecostals "represent approximately 70\% of the evangelical population in Argentina" (Wynarczyc 2019, p. 204).
} 
she currently advises Latin American Christian deputies in debates such as abortion, same-sex unions, assisted fertilization and euthanasia. In short, Hotton extended her political career by becoming a 'global' ambassador for Christian values in the partisan arena" (Carbonelli 2016, p. 208).

In the last PASO (Simultaneous Open and Compulsory Primary) elections in Argentina (2019), the NOS front is placed as the fifth political force. The NOS Front presented former military officer Juan José Gómez Centurión and former evangelical deputy Cynthia Hotton as presidential candidates. It is a new political proposal that opposes abortion by capitalizing on what is known as the "celestial vote" (pro-life and pro-family). Likewise, the evangelical churches demonstrated in Argentina a relevant power of convocation in the demonstrations during the debate for the legalization of abortion. According to the Second Survey of CEIL-CONICET (2019), this is a conglomerate that covers $15.3 \%$ of the Argentinian population (13\% are Pentecostals and 2.3 others are Evangelicals), a religious phenomenon that has experienced a strong growth in the last 50 years (the 1960 census showed them to be $2.3 \%$ ). ${ }^{5}$

Other relevant evangelical figures in politics are Miriam Ruth Boyadjian (National Senator of the Fuegian Popular Movement for the province of Tierra del Fuego between 2015 and 2019) and David Schlereth (deputy of the nation for the period 2017-2021, Pro party, evangelical pastor). There are also numerous evangelicals elected as councilors in municipal legislatures (Wynarczyc 2019, p. 216). There are also evangelicals in the worship offices of municipalities and provincial governments (García Bossio 2017).

In Argentina, as Frigerio (2019) and Algranti and Mosqueira (2018) point out, the evangelical churches work on abandoned domains of society, such as people who have addictions, people deprived of liberty, victims of gender violence, everything that has led to say that evangelicals work in the "basements" of the nation.

Public policies are the great capital of the evangelical world, the ability to mediate between the State and the territory. There is a structural weakness in the State's public policy and its ability to reach the territory, which is why it needs help "wheels" to be effective. For this reason, evangelicals have been progressively resorted to, especially on issues in which they have experience: the social, prisons and drug addiction.

The Argentinean anthropologist Alejandro Frigerio (2019), emphasizes that the growth of the evangelicals is due more to the contacts that the individual has with members of the group than to the publicity made in the media. The evidence indicates that "television and radio programs do not have the success that is usually assigned to them in the proselytizing function". The author points out that Pentecostal believers are connected to a new network of personal relationships when they enter a church, which improves their access to the circulation of goods and services for subsistence in precarious conditions: "labor assistance, care of children or the elderly, housing for migrants, access to housing and information about jobs or services" (Frigerio 2019, p. 52).

\footnotetext{
${ }^{5}$ For the Argentinian case see also Marcos Carbonelli (2016); Pablo Semán's contribution (2001, 2019) on the Evangelicals Theology of prosperity.
} 
In Argentina, the relationship between the Catholic Church and the State, due to its greater public visibility and its monopolistic position, is the most evident in the game of relations and negotiations existing between the religious and political fields; as well as it was the one that occupied a vast academic bibliography in the studies of religion and politics. However, Algranti (2010) studies from another perspective, at a more micro level, those aspects that are closer to everyday practices than to major public events. The author gives an account of other ways of doing politics based on how a neo-Pentecostal church ("King of Kings") was able to conquer those spaces that both the State and the Catholic Church left free, based on a structure that enables multiple and changing forms of intervention in society within which party politics, the State and civil society can move to the center of the scene. "King of Kings" has an "outward" model of Church, where religious orientations to the world are explored from three keys: the forms of violence and social suffering, the collective construction of a diagnosis on the situation of the country and the positioning of "Christian leaders" as agents of social transformation. The field of action of neo-Pentecostalism will be the subject, the values, the family, the neighborhood, the work environment, the social needs and other areas discredited by politics. Religion, "the Gospel", is a proposal for social change that is superimposed on all spheres of life. For this reason, the "King of Kings" church stands out for acting in specific spaces in the field of family, education and social assistance but does not have a relevant participation in party politics (Algranti 2010).

In this section, it is worth mentioning the study by Algranti and Mosqueira (2018) that reports on the evangelical rehabilitation of drug users in Argentina. The aforementioned authors point out that from the 1990s to the present day, neopentecostalism is moving towards "a growing institutionalization of its presence in society" (Algranti and Mosqueira 2018, p. 306). This is due to several factors: (1) they establish themselves in public space; (2) they increase the complexity of their organization; (3) they have a greater geographical reach in higher income areas; (4) they build the capacity of leaders with political influence and in the media; (5) cultural industries are supported by new technologies; (6) they create foundations to assist disadvantaged sectors; (7) they build a Christian youth subject from circuits of events. What the authors really highlight is the creation by evangelicals of models of intervention in abandoned areas of society, in less visible areas such as prisons, institutes for minors and work with problematic consumption, thus developing a specific methodology in the treatment of addictions from a spiritual perspective (Algranti and Mosqueira 2018). There are numerous studies that point out that religiosity is a protective factor against drug consumption in different cultural contexts.

The authors show that the State and religious groups converge in the Inclusion Program for the treatment of addictions, demonstrating that there is an articulation between public and evangelical networks, between the religious world and the world of public policy. "Evangelicals become actors through which the State executes health policies on problematic consumption, capitalizing on their territorial scope, methodology and experience. And, in turn, the government structures introduce -not without tension and resistance -the spiritual point of view in the development of public policies, that is, in the programs and action plans that allow the State to define priorities and act on them" (Algranti and Mosqueira 2018, p. 318). 
Mosqueira (2019) also develops how evangelical rock music made viable the development of Pentecostal evangelism in the youth sectors, revealing the transnationalization of a cultural industry aimed at evangelical youth. A recent survey carried out among Argentinean evangelical youth shows that they relate to God through personal prayer (53\%) and in second place through music $(31.3 \%)$. Only $10 \%$ claim to do so through the Bible. "These data show the great importance that the phonographic industry acquired in the evangelical environment and how its artisticreligious objects format and sensorize the connection with the divine" (Mosqueira 2019, p. 157).

In short, evangelicals have been involved in a cycle of collective protest action that began in the 1990s and ended in 2003. They fought for religious equality beyond mere religious freedom. Two key elements to understand the model of the political participation of evangelicals in Argentina is the territorial anchorage and affinity with Peronism.

Another singularity of the Argentine case is that the majority of evangelical voters do not have a preference for right-wing parties, but for center-left parties, more specifically, they agree with Peronism. This marks a difference with Brazil and Uruguay, where mostly Pentecostal evangelicals associate with right-wing parties. Taking into account the typology of Pérez Guadalupe (2019), in Argentina today we find the model of the "Evangelical faction", since in the past there were confessional political parties and they failed. In the Argentine case, the particularity is that the evangelical groups have failed through partisan means, but they have consolidated a mobilization in the streets and have penetrated public policies, as is the case of the care of people with problematic drug use.

There is no correlation in Argentina between evangelical demographic growth and the place reached in political office, and this perhaps is due to the fact that the political class still has the Catholic world as a reference.

\section{Evangelicals advance on the Uruguayan political scene}

Uruguay, the continent's most secular country, is slowly beginning to perceive the rise of political figures publicly recognized as evangelicals in the political arena. The first evangelical to burst into the Uruguayan political arena is Deputy Dr. Gerardo Amarilla (National Party), a lawyer and member of the Evangelical Baptist Church. Amarilla was a deputy for the department of Rivera in the 2010-2015 period and is reelected for the 2015-2020 and 2020-2025 periods, having held the post of mayor of the Rivera City Hall in the 2000-2010 period. Amarilla was the one who formulated the controversial phrase when he assumed his seat: "God's Law is above the Republic". Another relevant figure when we talk about politics and religion is Deputy Alvaro Dastugue, elected by the National Alliance sector, National Party. Dastugue is the first Evangelical Pastor in the history of Uruguayan politics to occupy a seat; his institutional affiliation is the neo-Pentecostal Church "Mission Life for the Nations" (Misión Vida para las Naciones), whose most relevant figure is the Apostle Jorge Márquez. The third political figure in the evangelical sphere is Benjamín Irazábal, Herrerista deputy for Durazno, also a member of the National Party. In 
addition to the three deputies mentioned above, a substitute deputy (Luis Pintado) for the Colorado Party (which had taken over the seat in 2018 after the resignation of the office bearer) and two nationalist deputies were added to the three deputies for the period 2015-2020: Betiana Britos (National Party, Alianza Nacional sector) and Grisel Pereyra (National Party, Esperanza Nacional sector). All of this led to the beginning of discussions in the last five years about the existence of an "evangelical group". Its members have denied it, claiming not to have their own agenda or specific coordination. Currently, there are more than a dozen evangelical councilors (office bearers and supplies) in the departmental governments and two positions of trust in the Rivera and Cerro Largo mayors' offices.

At the beginning of the last legislature (2015-2020), sixteen people (including deputies, councilors and trusted officials) received the blessing in a ceremony called "Consecration to Christians in Government". ${ }^{6}$ In it they committed themselves to respect the Constitution and the laws "as long as they do not contradict the word of God". They assured that they would abide by "the dictates" of their consciences "informed by the Word of God, above all personal or party allegiance," and said that the "basis" and "foundation" for their activity would be the Gospel. There are seven areas of Uruguayan society where evangelicals are working in politics and seeking to have influence: government, church, family, economy, culture, arts and communication. ${ }^{7}$

Without a doubt, the main political figure of the evangelical voters has been a woman belonging to the National Party, Catholic, converted to Judaism: the former nationalist senator Veronica Alonso (period 2015-2020). Alonso was one of the most visible political figures against the "trans" law when it was discussed in Parliament. She embodies the same values promoted by the neo-Pentecostal churches, mainly the value of the traditional family and the defense of the value of life. Alonso has raised the shadow of the officialdom because of the alleged contribution of the Mission Life for the Nations Church in the financing of its past campaign (2014), since an unpaid bill was left in a printing press in the name of a person related to the church (Gabriel Cunha), which led to a legal dispute. The contribution of the religious people to Alonso's campaign was analyzed by the Commission of Inquiry into the financing of political parties and the complaint of inmates of Hogar Beraca handing out their lists was investigated by the Human Rights Commission of the Parliament for labor exploitation of the young inmates in that community.

According to Guadalupe's and Grundberger (2019) typology, the insertion of evangelicals in Uruguayan political parties corresponds to the third model, that is to say to the "Evangelical faction", to which evangelical candidates are inserted in already established political parties. In the Uruguayan case, it would be very surprising if it could have been otherwise due to the very strong legitimacy of the three main political parties, two of them true founders of the country since the nineteenth century, which are among the oldest parties in the world (the National Party and the

\footnotetext{
${ }^{6}$ See full ceremony "Consagración a cristianos en el gobierno" 13 September, 2015 on: https://www. youtube.com/watch?v=Tm3Px6CzqW4.

7 See https://www.elpais.com.uy/que-pasa/evangelicos-banca.html
} 
Colorado Party), together with the left wing (Frente Amplio), which has been united for half a century and came to govern the country between 2005 and 2020. These political identities make extremely difficult, at least so far, the emergence of new parties, let alone religious confessional parties in a country that cultivates republican secularism. That is why the participation of evangelicals in Uruguayan politics has been from within established parties, or even occupying positions in the administration of both the national and departmental governments.

Currently the evangelicals are carrying out a strong offensive against the "rights agenda", even in 2019 they collected signatures for a pre-referendum to repeal the Integral Law for Trans people, which finally was not successful. ${ }^{8} \mathrm{Mr}$. Carlos Iafigliola, a politician belonging to the National Party, who was pre-candidate for president of his party in the internal elections of June 2019, was the promoter of the pre-referendum. Iafigliola identifies himself as a charismatic Catholic and had the support during this process of the evangelical neo-Pentecostals, mainly Congressman Alvaro Dastugue of the Evangelical Neo-Pentecostal Church Mission Life for the Nations. Iafigliola justified his initiative by saying that the "trans" law is "unconstitutional, dangerous and unjust" (Universal Radio, November 14, 2018). He developed his thoughts by saying that they have been following the project since it was presented by former trans senator Michele Suárez of the Broad Front Party (Partido Frente Amplio), and they saw it as dangerous to give a framework to the possibility that minors can carry out processes of hormonalization and sex change. He affirms that, although any older person can have a sex change, it is unfair that the State guarantees the process free of charge, since it does not manage to cover basic needs in health matters, high cost medicines or surgeries.

On the other hand, it is also worth noting that the neo-Pentecostal evangelicals are against sex education in schools, as has been stated in several occasions by the leader of the Mission Life for the Nations Church, Pastor Marquez, pointing out that "the government's sexuality manuals incite pedophilia and that the "gay lobby" seeks to legalize sex with minors (Weekly 2018).

Regarding abortion, evangelicals condemn the practice and have stated in numerous press interviews that they intend to repeal the law in the next legislative period. Proof of this is a project presented in 2016 by Dastugue and Irazábal—which did not

\footnotetext{
${ }^{8}$ In November 2012 the Voluntary termination of pregnancy Act, Law No 18,987 was passed establishing that termination of pregnancies complying with the requisites provided by virtue of the new law (among which it has to be carried out within the first twelve weeks of pregnancy). In Uruguay, since August 2013 the Same Sex Marriage Act is in force, acknowledging the civil marriage between people of the same sex as legitimate. (Law No 19,075 and Law No 19,119). In 2013 The Uruguayan Parliament passed the Regulation and Control of Cannabis Act (Law No 19,172), by means of which a legal marihuana market controlled by the State is created. Law No 19,172 provides the creation of the Institute for the Regulation and Control of Cannabis (IRCCA) with the aim of regulating the planting, crop growing, harvest, production, processing, storage, distribution and dispensing of cannabis. The Integrated Law for transgender people was passed in October 2018. (Law No 19,684). This law provides for the creation of public policies addressed to this population. Through the design and promotion of affirmative actions public and private ones-it is meant to decrease the structural and permanent discrimination trans people go through, promoting the inclusion thereof in the fields they have been historically excluded; namely the social, educational, cultural, economic, working, medical.
} 
succeed-to celebrate the "Day of the Unborn Child" on 25 March. The referendum to repeal the law to decriminalize abortion in 2013 did not reach the necessary signatures, but this does not ensure the persistence of the law, since Iafigliola himself promises to continue working to eradicate it.

Regarding drug consumption, Congressman Alvaro Dastugue has said that the discussion in Parliament of the Marijuana Regulation Act has been what has pushed him to have an active role in politics. The reason for this is that in the Beraca homes of the Mission Life Church, social work is carried out to attend to users who present a problem with drug consumption, and it is for this reason that they are against this law.

The evangelicals also weave alliances with social movements and pro-life and pro-family NGOs, such as the one in Uruguay called "My children are not touched," which emerged as a rejection to the didactic proposal for addressing sex education in early and primary education, presented by the CEIP (Early and Primary Education Council).

During some months of the year 2019, for the first time in the political history of Uruguay, four evangelical deputies met in Parliament. During that five-year legislative period, eleven initiatives were presented by evangelical legislators following the same religious convictions: two projects against the decriminalization of abortion, four bills associated with the prohibition and treatment of drugs, four that promote the "traditional" family, and one that establishes October 31 as the "National Day of the Evangelical Churches".

Finally, the issue of egalitarian marriage is also a flank to which the evangelicals point, since the family model they defend is the nuclear family, composed of a man and a woman. It is therefore that they also oppose such law already approved in our country.

Uruguayan sociologist Da Costa (2009) explores the characteristics of Uruguayan secularism, analyzing its main landmarks and political and cultural significance. The author analyzes the process that led to the institutional separation of the Catholic Church and the State in 1919, as well as the shift from the religious to the private, the legal formulation of secularism and the cultural imprints that impregnated, as a matrix, the vision and location of religion in Uruguay until almost today. The French case, says Da Costa (2009), with its strong charge of enlightenment and Jacobinism, is the one that inspired the construction elites of the Uruguayan State in the late nineteenth and early twentieth centuries, when a strong confrontation took place in Uruguay between the emerging Uruguayan State, which claimed for itself the control of various aspects of collective life, and the Catholic Church, which administered certain spaces that today we understand as belonging to the State. However, in our country, "the cultural expression of Uruguayan secularism shows in practice higher levels of radicalism than in the French case" (Da Costa 2009, p. 1). ${ }^{9}$

Guigou (2006) refers to the public presence of neo-Pentecostalism in Uruguay, at least since the 1980s, and refers to the "neo-Pentecostalization of the political

\footnotetext{
${ }^{9}$ Caíque Bellato has very recently presented his PhD Dissertation at PUC Rio de Janeiro: "Sob a lei de Deus: evangélicos e política no Uruguai" (2020), a superb work on Uruguayan laicism and the new push of evangelicals in politics.
} 
language", but at that time he states that "there are no evangelical benches, nor different nominations from the Pentecostal universe disputing positions in the political arena" (Guigou 2006, p. 51). This diagnosis no longer coincides with reality and shows how changes have been rapidly unleashed in this religious and political scenario that mobilize us to think about the phenomenon from a new sociological perspective. More recent actors in this overlap between religion and politics are the examples mentioned of the evangelical deputies and their concrete action in search of a "Christian morality" that is based on the model of the traditional, patriarchal, heterosexual and "drug-free" family (Scuro 2018, p. 55).

Scuro (2018) also analyzes the arrival of other religious leaders to the parliamentary sphere, such as the case of Mae Susana Andrade (ex-deputy of African descent for the Broad Front Party) or the evangelical deputies Gerardo Amarilla, the neo-Pentecostal pastor Álvaro Dastugue and Benjamín Irazábal. The author concludes that "Moralities, identities and freedoms are in a vigorous political dispute in Uruguay. The interpretative framework of secularism is an important axis through which the attempts to materialize these bids by the different sectors involved are manifested. The political sphere in a strict sense (partisan) is one of them. The presence of religious symbols in the public space is another obvious way of making the processes of identification and dispute visible" (Scuro 2018, p. 55), (Bayce 2017).

Iglesias (2019), another scholar of the relations between religion and politics in Uruguay today in his contributions mentions that the most relevant fact of 2019 between religion and politics was the strong activity of the neo-Pentencostals militating against the Integral Law for Trans People, which was carried out by the deputy Carlos Iafigliola, a charismatic Catholic, and the deputy Álvaro Dastugue, a neo-Pentencostal pastor of the church Mission Life for The Nations. Although, as we said, the vote was not enough to advance in the repeal of the law, this movement allowed two things: "on the one hand, it motivated the involvement of the religious conservative bases of these sectors under the same cause, and on the other hand, it offered the possibility of training people in political work and having more experience for the elections. It is important to note that in this vote in the departments bordering Brazil, Evangelicals obtained the greatest number of supporters, which shows a certain internationalization of the phenomenon and the influence of the neighboring country.

Magdalena Milsev, an uruguayan antropologyst, also studies the church Mission Live for The Nations in Uruguay in her master's thesis. She presents ethnographical examples where we can find political effects of practices and discourses that are not usually conceived as political-religious doctrine, biblical hermeneutics, moral discourses-which are connected with the conservative activism of this church. "This last point—easily identified as "political" as it is associated with a party—is just one of the many levels in which politics are present in this neopentecostal cosmological order" (Milsev 2019, p. 327). The author points out that neopentecostals 
megachurches have constantly grown in Uruguay since their arrival in the eighties, and despite of the hegemonic rejection and the cited secular roots of the state, "they have acquired social-and political-relevance, as they have achieved to reach popular sectors, providing social services where the state is not present, as well as powerful symbolical referents for people in situation of deprivation" (Milsev 2019, p. 328). Mission Life Church has been actively participating in matters of public agenda since the innovations concerning sexual and reproductive rights started to be discussed - which in our country adds also the Legalization of Cannabis-something that has happened broadly at a regional level in relation to religious conservative denominations. In this sense, they continue working against abortion and homosexual marriage despite the fact that they were legalized in 2012 and 2013, persevering on discourses along with an active campaign against the Sexual Education Guide of Public Education and the "Trans Law" (Milsev 2019), as we have already pointed out.

\section{Conclusions}

The evangelical population of Brazil (26\%), Argentina (12\%) and Uruguay (7\%) has grown steadily in the last decades. This growth has impacted the political arena of the three countries studied in this paper, Brazil, Argentina and Uruguay in different ways. We showed the complexity of the analysis of the relationship between evangelicals and politics. There are common elements in spite of the structural differences among the three countries but, naturally, there are also specific differences. What is striking in the three cases is that there is a common pattern in the agendas chosen to give the political dispute from the evangelical congregations. Their great objective is to weaken the new rights agenda towards the LGBT movements, legal abortion, equal marriage, to go against the so-called gender ideology and to propose a supposed law of God over legal law. It is a tremendously conservative and patriarchal agenda in all three cases, which is articulated internationally. Today, in various public debates in the three countries analyzed, more and more Evangelicals are assuming themselves to be conservative and right wing and claim that their religious values and way of life are under fierce attack by their enemies, identified as the left, the petitioners, the Communists, the Bolivarianists, the feminist and LGBT groups, the defenders of the secularity of the State, and of human and sexual rights.

Also, the territorial anchoring and the social work carried out by the evangelical churches in the most marginalized territories is a common pattern that we find in the three countries. They work hard in the sewers of society, with drug addicts, alcoholics, women that suffered domestic violence, convicts, slums, unemployed. Innumerable amounts of their temples can be seen in the margins of society, where the poorest of the poor survive. And the religious worshippers with which the rituals are developed are always people that tell their story life journey from sin to light, from theft to honesty, from drug use to sober, from violence to peace. The cause of these substantial self-transformations is attributed to the discovery of God through the intermediation of the pastors. All the legitimacy gained by 
evangelicals working in these territories and social contexts is then capitalized in political participation.

But it is also significant to show the differences of degree in the political articulation of these groups. Brazil is the most advanced case in crystallizing an agenda in parliament with a powerful legislative bench that even includes President Bolsonaro himself in its strategies and tactics. Uruguay has also seen a considerable increase in evangelical representatives in parliament in the last decade, although they deny that a group like Brazil's exists. Clearly, a plausible hypothesis is that the evangelical influence has contributed to deciding the last Uruguayan national elections, which were decided on the ballot by barely twenty-five thousand votes. In the case of Argentina, although an evangelical deputy was highlighted, they have acted much more at the social and territorial base level, seeking to influence public drug policies, for example, but with little interest until now in the direct dispute for positions of political representation. Precisely, part of their convening power was seen on the streets in a rally against the abortion law. In Brazil we find the simultaneous presence of the three models of political participation defined by Pérez Guadalupe: Evangelical parties, Evangelical front and Evangelical faction. On the other hand, the production of "Politicians of Christ" stands out in this case (the churches adopt official candidates and promote them to their faithful) and the performance of the churches as parallel parties. All this occurs in a context of high party fragmentation (political parties are weak and have diluted borders) and the magnitude of electoral districts. There is also a significant difference in Brazil, where the motto "brother votes brother" is getting considerable compliance among the evangelical followers. This is not the case in the other two countries, where the demographic growth of evangelicals is not fully translated to votes for evangelical politicians. Neither in Argentina nor in Uruguay the first two models have evolved, but we can see clearly the presence of the Evangelical factions, where evangelicals choose to participate in politics from within wellestablished parties as it is the case with Peronism, or with all three main political parties in Uruguay, but with a notorious preference for the National Party.

Acknowledgements Our thanks to Kym Simmons (Australia) and Clara Cnudde (Uruguay) for their help in translating the article.

Funding No funding was received to assist with the preparation of this manuscript.

Data availability The datasets generated during and/or analyzed during the current study are available in the Latinobarómetro repository: Latinobarómetro Database (latinobarometro.org).

\section{Declarations}

Conflicts of interest The authors have no conflicts of interest to declare that are relevant to the content of this article.

Open Access This article is licensed under a Creative Commons Attribution 4.0 International License, which permits use, sharing, adaptation, distribution and reproduction in any medium or format, as long as you give appropriate credit to the original author(s) and the source, provide a link to the Creative Commons licence, and indicate if changes were made. The images or other third party material in this article are included in the article's Creative Commons licence, unless indicated otherwise in a credit line to the 
material. If material is not included in the article's Creative Commons licence and your intended use is not permitted by statutory regulation or exceeds the permitted use, you will need to obtain permission directly from the copyright holder. To view a copy of this licence, visit http://creativecommons.org/licen ses/by/4.0/.

\section{References}

Algranti J (2010) Politics and religion in the margins. New forms of social participation of evangelical megachurches in Argentina. Ciccus Editions, Buenos Aires

Algranti J, Mosqueira M (2018) Sociogenesis of Evangelical "rehabilitation" devices for drug users in Argentina. Salud Colectiva 14(2):305-322

Argentina Constitution of the Argentine Nation (1853) Available on the website of the Ministry of Justice and Human Rights. http://www.saij.gob.ar/nacional-constitucion-nacion-argentina-lnn00026651853-05-01/123456789-0abc-defg-g56-62000ncanyel

Bayce R (2017) Evangelicals advance in politics and religion. Caras y Caretas Magazine, Montevideo. Retrieved from: https://www.carasycaretas.com.uy/los-evangelicos-avanzan-politica-religion/

Bellato, C (2020) Sob a lei de Deus: evangélicos e política no Uruguai", PhD Dissertation PUC Rio de Janeiro

Brecha Weekly (2018) Evangelicals and their link to politics. They are coming down. November 9th, 2018. Written by Daiana García

Burity, J (2008) Religion, politics and culture. Tempo Social. Journal of Sociology of USP Vol 2

Campos Machado MD (2018) Christian discourse on "gender ideology". Estudos Feministas Magazine. Florianópolis 26(2):47463

Carbonelli M (2016) Evangelicals and the party arena in contemporary Argentina. Estud Polít 37:193-219

Carbonelli M, Jones DE (2015) Religious equality and state recognition: evangelical institutions and leaders in the debates on the regulation of religious activities in Argentina, 2002-2010. Mexican Journal of Political and Social Sciences. National Autonomous University of Mexico. Nueva Época, Year LX / No. 225. September-December 2015:139-168

CEIL-CONICET (2019) Second National poll on religious beliefs and attitudes. Society, culture and religion programme.

Cernadas CC (2014) Configurations of power in the indigenous Evangelical field of Argentinian Chaco. Soc Relig J 24(41):13-42

"Consecration to Christians in Government" September 13, 2015 at: https://www.youtube.com/watch?v= Tm3Px6CzqW4

Da Costa N (2009) Uruguayan laicism. Arch Sci Soc Relig 146:137-155

Freston P (1993) Protestants and politics in Brazil: from Constituent to impeachment (Doctoral thesis). Institute of Philosophy and Human Sciences, University of Campinas, São Paulo, IFCH

Freston P (2012) The two future transitions: Catholics, Protestants and Society in Latin America. In: Parker C (ed) Religion, politics and culture in Latin America: new perspectives. Institute for advanced studies. University of Chile. Association of Social Scientists of the Religion of the Southern Cone, Chile

Frigerio A (2019) The Pentecostal religious experience. New Soc 280:47-67

García Bossio MP (2017) Municipal agencies in connection with the religious in the Province of Buenos Aires: forms of local state regulation of diversity. Document presented at the XVI Interschool Conference/History Departments, Faculty of Humanities, National University from Mar del Plata, Argentina

Guigou N (2006) Religion and politics in Uruguay. Civil Soc Sci J 6(2):43-54

Iglesias N (2019) The political religious map towards the next elections. La Diaria, Montevideo

Latinobarómetro (2018) Database of the 2018 survey. Processed on-line from www.latinobarometro. org.

Lacerda F, Brasiliense JM (2019) Brazil: the Pentecostals' incursion into the Brazilian legislative power. In: Pérez-Guadalupe JL, Grundberger S (eds) Evangelicals and power in Latin America. Konrad Adenauer-Institute of Christian Social Studies, Lima, pp 223-259

Levine D (2006) Religion and politics in Latin America. The new public face of religion. Soc Relig 18:7-29 
Maia ELC (2006) Evangelicals and politics. Electron J Post-Grad Polit Sociol UFSC 2(4):91

Mallimaci F (ed.) (2008) Religion and politics. Perspectives from Latin America and Europe. Buenos Editorial Biblos, Aires

Mallimaci F, Cruz-Esquivel J (2013) The triad State, religious institutions and civil society in contemporary Argentina. Amerika [enligne] 8:2013. https://doi.org/10.4000/amerika.3853

Mariano R (2005) Pentecostalism and politics in Brazil. Sci Relig 5(2):119-133

Milsev M (2019) Politics in the temple: religious doctrine and conservative activism in a neopentecostal church in montevideo: a brief approach. Int J Latin Am Relig 3(2):289

Mosqueira M (2019) God and rock \& roll: how evangelism transformed rock. New Society. 280:68-77

Newspaper. El país (2015) Evangelicals who have a parliamentary seat Retrieved from https://www. elpais.com.uy/que-pasa/evangelicos-banca.html

Oro AP (2003) The Universal Church Policy and its reflexes in the Brazilian religious and political fields. Revista Brasileira De Ciencias Sociales 18(53):1-5

Oro AP, Tadvald M (2019) Considerations on the Brazilian evangelical field. New Soc Mag 280:55-67

Oualalou L (2019) The evangelicals and brother Bolsonaro. Nueva Soc. 280:68-77

Pérez-Guadalupe JL (2019) Evangelical politicians or political evangelicals. The new models of political conquest of the evangelicals? In: Pérez-Guadalupe JL, Grundberger S (eds) Evangelicals and power in Latin America. Konrad Adenauer-Institute of Christian Social Studies, Lima, pp 13-22

Scuro J (2018) Religion, politics, public space and secularism in Progressive Uruguay. Horizont Antropol 24(52):41-73

Segato R (2008) The factionalism of the republic and the religious landscape as an index of a new territoriality. Latin America and the Caribbean. Religious territories and challenges to dialogue. Aurelio Alonso (comp.). CLACSO, Buenos Aires.

Semán P (2001) The popular reception of the theology of prosperity. Scri Ethnol 18:45-162

Semán P (2019) Who are they? Why do they thrive? What do they believe in? Pentecostalism and politics in Latin America. Nueva Soc 280:26-46

Silveira Campos L (2005) From "Evangelical politicians" to "Christ's politicians": the trajectory of the political actions and mentality of Brazilian evangelicals in the passage from the 20th to the 21st century. Ciencias Sociales y Religión, Year 7(7):157-186

Universal Radio (970 AM). November 14th, 2018. https://970universal.com/2018/11/14/la-ley-trans-esinconstitucional-peligrosa-e-injusta/

Uruguay. Law No 18.987. Voluntary termination of pregnancy. Passed on 22 October 2012. Uruguayan Parliament. Available on: https://legislativo.parlamento.gub.uy/temporales/leytemp8986273.htm

Uruguay. Law No 19.075. Same sex marriage Act. Passed on 3 May 2013. Uruguayan Parliament. Available on: https://legislativo.parlamento.gub.uy/temporales/leytemp8466022.htm

Uruguay. Law No 19.172. Marihuana and its by-products: State control and regulation of the import, production, purchase, storage, trading and distribution. Passed on 20 December 2013(b). Uruguayan Parliament. Available on: https://legislativo.parlamento.gub.uy/temporales/leytemp457807.htm

Uruguay. Law No 19,684. The Integrated Law for transgender people Act. Passed on 26 October 2018. Uruguayan Parliament. Available on: https://legislativo.parlamento.gub.uy/temporales/docu930336 8853866.htm

Vilaça A, Wright RM (eds) (2009) Native Christians: Modes and effects of christianity among indigenous Peoples of the Americas. Ashgate, Farnham, pp 12-252

Wright $\mathrm{P}$ (2008) The peripheral religions and ethnography of Latin American modernity as a challenge to religious sciences. Caminhos Magazine. Goiânia, 6(1), 83-99

Wynarczyk H (2009) Citizens of two worlds. The Evangelical Movement in the Argentinian Public Life 1980-2001. UNSAM, Buenos Aires

Wynarczyk H, Oro AP (2012) Pentcostalism in Latin America. Religioni e Società 28:27-73

Wynarczyk H (2019) Argentina: new wine in old odres? Evangelicals and politics. In: Pérez Guadalupe JL, Grundberger S (eds) Evangelicals and power in Latin America. Konrad Adenauer-Institute of Christian Social Studies, Lima, pp 193-222 